\title{
A fossil unicorn crestfish (Teleostei, Lampridiformes, Lophotidae) from the Eocene of Iran
}

\author{
Donald Davesne ${ }^{\text {Corresp. } 1}$ \\ 1 Department of Earth Sciences, University of Oxford, Oxford, United Kingdom \\ Corresponding Author: Donald Davesne \\ Email address: donald.davesne@earth.ox.ac.uk
}

Lophotidae, or crestfishes, is a family of rare deep-sea teleosts characterised by an enlarged horn-like crest on the forehead. They are poorly represented in the fossil record, by only three described taxa. One specimen attributed to Lophotidae has been described from the pelagic fauna of the middle-late Eocene Zagros Basin, Iran. Originally considered as a specimen of the fossil lophotid +Protolophotus, it is proposed hereby as a new genus and species. $†$ Babelichthys olneyi, gen. et sp. nov., differs from the other fossil lophotids by its relatively long and strongly projecting crest, suggesting a close relationship with the modern unicorn crestfish, Eumecichthys. This new taxon increases the diversity of the deep-sea teleost fauna to which it belongs, improving our understanding of the taxonomic composition of the early Cenozoic mesopelagic ecosystems. 
1 A fossil unicorn crestfish (Teleostei, Lampridiformes, Lophotidae) from the

2 Eocene of Iran

3

4 Donald Davesne ${ }^{1}$

$5{ }^{1}$ Department of Earth Sciences, University of Oxford, South Parks Road, OX1 3AN Oxford,

6 United Kingdom

7 e-mail address: donald.davesne@earth.ox.ac.uk 


\section{ABSTRACT}

9 Lophotidae, or crestfishes, is a family of rare deep-sea teleosts characterised by an enlarged

10 horn-like crest on the forehead. They are poorly represented in the fossil record, by only three

11 described taxa. One specimen attributed to Lophotidae has been described from the pelagic fauna

12 of the middle-late Eocene Zagros Basin, Iran. Originally considered as a specimen of the fossil

13 lophotid $\uparrow$ Protolophotus, it is proposed hereby as a new genus and species. $\dagger$ Babelichthys olneyi,

14 gen. et sp. nov., differs from the other fossil lophotids by its relatively long and strongly

15 projecting crest, suggesting a close relationship with the modern unicorn crestfish, Eumecichthys.

16 This new taxon increases the diversity of the deep-sea teleost fauna to which it belongs,

17 improving our understanding of the taxonomic composition of the early Cenozoic mesopelagic

18 ecosystems. 


\section{INTRODUCTION}

Lampridiforms are strange spiny-rayed teleosts, found in mesopelagic environments in every ocean of the world (Olney, Johnson \& Baldwin, 1993; Olney, 2002). Their most famous representatives are the endothermic opah (Lampris guttatus) and the gigantic, serpentine oarfish (Regalecus glesne), the longest known teleost. Along with these iconic taxa, lampridiforms include equally weird ribbon-like and elongate animals, characterized by a silver-coloured skin and long, bright red fins: the taeniosomes. The 15 to 18 extant species of the clade Taeniosomi include oarfishes (Regalecidae), ribbonfishes (Trachipteridae), the tapertail (Radiicephalidae) and Lophotidae, the crestfishes (Regan, 1907; Walters \& Fitch, 1960; Olney, 1984; Roberts, 2012). Lophotids are characterized by unique structures, such as an ink gland (Walters \& Fitch, 1960; Honma, Ushiki \& Takeda, 1999) not found anywhere else in teleosts (except in the closely related radiicephalids; Harrisson \& Palmer, 1968). The most conspicuous osteological feature of lophotids is a well-developed horn-like crest, formed by an anteriorly projecting expansion of the frontal and supraoccipital bones of the cranium (Oelschläger, 1979, 1983; Olney, Johnson \& Baldwin, 1993). This crest is closely associated with the anterior pterygiophores supporting the dorsal fin, and as a result, the dorsal fin expands over, and sometimes anterior to the cranium. Lophotids are represented in modern fauna by one to three Lophotus species and by the unicorn crestfish, Eumecichthys fiski (Walters \& Fitch, 1960; Craig, Hastings \& Pondella, 2004). Their fossil record consists in at least three monotypic genera (Bannikov, 1999; Carnevale, 2004). The present article is a revision of an anatomically distinctive fossil specimen attributed to Lophotidae. Arambourg $(1943,1967)$ first described the specimen from a rich late Eocene fauna located near Ilam, Zagros Basin, Iran. The Ilam fauna comprises numerous representatives of teleost taxa such as Beryciformes, Gadiformes, Ophidiiformes and Stomiiformes, typical of the 
43 modern deep-sea pelagic environments (Arambourg, 1967; Afsari et al., 2014; Přikryl,

44 Brzobohatý \& Gregorová, 2016).

45 The taxonomic status of the lophotid specimen studied here is currently unclear (Walters, 1957;

46 Oelschläger, 1979; Bannikov, 1999), and it lacks a proper anatomical description. Given the

47 rarity of fossil material attributed to taeniosome lampridiforms, a detailed description and revised

48 taxonomy of this material is needed in order to improve our understanding of the morphological

49 evolution and fossil record of this peculiar group.

50

51 MATERIAL AND METHODS

52 Taxonomic status of the material

53 The material described herein, MNHN.F.EIP11 (Figs. 1, 2), was discovered during excavations

54 near Ilam (Zagros Basin, Western Iran) by Camille Arambourg in 1938-1939. The specimen was

55 chosen to be the paratype of $\dagger$ Lophotes elami (Arambourg, 1943), along with the holotype

56 MNHN.F.EIP10 (Fig. 3). On the basis of osteological differences from extant lophotids, such as

57 the well-ossified pelvic girdle in a ventral position observed in the holotype of $\uparrow$ Lophotes elami,

58 Walters (1957) assigned it to a distinct new genus $\uparrow$ Protolophotus (Fig. 3). Oelschläger (1979)

59 later proposed that MNHN.F.EIP11 differs sufficiently from MNHN.F.EIP10 to be classified in a

60 different genus. He related the specimen to the extant Eumecichthys and gave it the name

$61 \dagger$ Protomecichthys'. However, the genus $\dagger$ 'Protomecichthys' lacks both a designated type species

62 and a formal description. Thus, it fails to meet the requirements of Article 13.3 of the

63 International Code of Zoological Nomenclature (International Commission on Zoological

64 Nomenclature, 1999) and should be considered a nomen nudum (Bannikov, 1999).

65 


\section{Comparative material}

$67 \dagger$ Eolophotes lenis, PIN 1413/86; Eumecichthys fiski, USNM 164170 (radiographs); Lophotus

lacepede, NHMUK 1863.8.27.1 (radiographs); †Oligolophotes fragosus, PIN 3363/121;

$\dagger$ Protolophotus elami, MNHN.F.EIP10.

\section{Nomenclatural acts}

The electronic version of this article in Portable Document Format (PDF) will represent a published work according to the International Commission on Zoological Nomenclature (ICZN), and hence the new names contained in the electronic version are effectively published under that Code from the electronic edition alone. This published work and the nomenclatural acts it contains have been registered in ZooBank, the online registration system for the ICZN. The ZooBank LSIDs (Life Science Identifiers) can be resolved and the associated information viewed through any standard web browser by appending the LSID to the prefix http://zoobank.org/. The LSID for this publication is: urn:lsid:zoobank.org:pub:B677BA4F-CCF4-4678-A8A8502F059704D2. The online version of this work is archived and available from the following digital repositories: PeerJ, PubMed Central and CLOCKSS.

\section{Methods}

The specimen was examined with a stereomicroscope equipped with a camera lucida drawing arm. The interpretative drawing was produced with Adobe Illustrator CS6 from the camera lucida drawings and from photographs. Measurements were taken with a compass or with the software ImageJ 1.5 from radiographs; angles were also measured with ImageJ. The method for estimating the degree of projection of the crest is modified from Craig, Hastings \& Pondella 
89 (2004): it is based on the angle between the straight line from the tip of the crest to the proximal

90 end of its anterior margin (instead of the tip of the upper jaw, due to varying jaw positions in

91 fossils) and the vertical line drawn perpendicular to the main axis of the parasphenoid (instead of

92 the vertebral column, not preserved in MNHN.F.EIP11). The relative length of the crest is the

93 ratio between the crest length (distance between the tip of the crest and the proximal end of its

94 anterior margin) and the head length without the crest (from the anterior margin of the ethmoid

95 region to the posterior margin of the neurocranium). All extinct taxa are indicated with a dagger

$96(\dagger)$.

97

98 RESULTS

99 Systematic palaeontology

100 TELEOSTEI Müller, 1845

101 ACANTHOMORPHA Rosen, 1973

102 Order LAMPRIDIFORMES Goodrich, 1909

103 Suborder TAENIOSOMI Gill, 1885

104 Family LOPHOTIDAE Bonaparte, 1845

105 Genus $†$ Babelichthys gen. nov.

106 urn:lsid:zoobank.org:act:86986E5E-5FFF-465D-A987-E475FBF02966

107 (Figs. 1, 2)

108

109 Etymology. Hellenization of the name of the "Babel fish", the teleost-like, ear-dwelling, polyglot

110 extra-terrestrial species from Douglas Adams' 1979 book The Hitchhiker's Guide to the Galaxy,

111 in reference to the very peculiar, almost alien-like, appearance of the genus. 
112 Type and only species. $\dagger$ Babelichthys olneyi, sp. nov.

113 Diagnosis. A lophotid differing from $\uparrow$ Eolophotes, Lophotus, $\uparrow$ Oligolophotes and

$114 \uparrow$ Protolophotus by the relatively longer, strongly projecting crest; and from Eumecichthys by the

115 relatively shorter, deeper and less strongly projecting crest, with strongly expanded anterior

116 dorsal-fin pterygiophores.

117

$118 \dagger$ Babelichthys olneyi sp. nov.

119 urn:lsid:zoobank.org:act:D2540D1F-F169-40DE-B910-7302810615E7

120 (Figs. 1, 2)

121

$1221943 \dagger$ Lophotes elami Arambourg, p. 287, pl. X, fig. 1

$1231957 \dagger$ Protolophotus elami Walters, p. 60

$1241967 \dagger$ Protolophotes elami Arambourg, pl. VI, fig. 1

$1251979 \dagger$ Protomecichthys sp. Oelschläger, p. 354, fig. 11 (nomen nudum)

126

127 Holotype. MNHN.F.EIP11d/g, almost complete articulated cranium and anterior portion of the

128 dorsal fin, in part and counterpart (Figs. 1, 2). This is the only specimen known for the genus and

129 species.

130 Etymology. Species named in honour of the late John E. Olney, in recognition of his work on the 131 anatomy and ontogeny of Lampridiformes.

132 Type locality and horizon. Near Ilam, Zagros Basin, Western Iran. This teleost fauna, part of 133 the Pabdeh Formation, was erroneously aged Cretaceous by Priem (1908), and Rupelian 
134 (Oligocene) by Arambourg $(1943,1967)$. It is more accurately middle to late Eocene in age

135 (Afsari et al., 2014; and references therein).

136 Diagnosis. As for the genus.

137

\section{Anatomical description}

139 MNHN.F.EIP11 consists only of the head of the animal, along with the associated anterior

140 portion of the dorsal fin. The specimen is mostly articulated, except for the left ventral portion of

141 the hyoid arch that is upturned and preserved ventral to the rest of the cranium. The limits of

142 most bones are poorly preserved, probably due to their low degree of mineralization in life as is

143 the case in modern taeniosome lampridiforms.

\section{Measurements}

146 Total head length: $104 \mathrm{~mm}$; head length (without the crest): $44 \mathrm{~mm}$; crest length (anterior

147 margin): $51.5 \mathrm{~mm}$; head depth: $25.5 \mathrm{~mm}$; orbit diameter: $23 \mathrm{~mm}$.

\section{Neurocranium}

150 The neurocranium of MNHN.F.EIP11 is highly modified. The frontal develops a dorsal lamina 151 that projects anterior to the jaws. Throughout approximately its anterior half, it is in contact with an enlarged laminar process of the supraoccipital, delimited dorsally by a strong supraoccipital spine. Together, they form a conspicuous "crest", long and strongly projecting anteriorly (at an angle of $64.5^{\circ}$ ). Alone, the crest contributes to $58 \%$ of total head length.

155 The frontal makes up approximately $60 \%$ of the anterior margin of the crest. Both the frontal and 156 the supraoccipital show radial ornamentation on the crest; it radiates from the posterior end of 
157 the frontaland the distal tip of the supraoccipital. The supraoccipital spine borders the dorsal

158 margin of the bone, narrowing towards the tip.

159 The ethmoid region is poorly preserved, with an enlarged probable lateral ethmoid hiding the

160 mesethmoid. An enlarged lachrymal is nested in the antero-ventral corner of the orbit; it is

161 parallel to the parasphenoid ventrally, and curves dorsally along the edge of the lateral ethmoid.

162 The orbitosphenoid runs along the dorsal margin of the orbit and has a conspicuous process

163 pointing ventrally. The posterior wall of the orbit is delimited ventrally by a robust and straight

164 basisphenoid. Otherwise, the sphenoid, otic and occipital regions are too poorly preserved to

165 distinguish the individual bones. The parasphenoid is robust and slightly curves dorsally at its

166 anterior end. The junction between the parasphenoid and the vomer is not discernable. There is

167 no evidence of vomerine teeth.

168

169 Jaws

170 The premaxilla is relatively small, with a well-developed ascending process, and a barely visible

171 alveolar process. The maxilla bears a conspicuous and pointed process at its antero-dorsal end.

172 The posterior end is expanded dorsoventrally, forming a rounded lamina. Neither the premaxilla

173 nor the maxilla bear visible teeth. There is no evidence of a supramaxilla. The anterior margin of

174 the dentary, slightly concave and bearing no visible teeth, forms a strong angle with the ventral

175 margin. The posterior margin of the dentary forms an interosseous space with the

176 anguloarticular, which is mostly hidden by overlaying bones.

177

178 Suspensorium and hyoid arch 
179 Only the proximal, single-headed articulation of the hyomandibula is clearly visible; the distal 180 end of the bone seems to be preserved in close association with the metapterygoid. The latter is 181 roughly triangular and is one of the best preserved bones of the suspensorium. The symplectic is

182 rod-like, narrows slightly anteriorly and inserts in a notch on the postero-ventral margin of the 183 quadrate. The triangular quadrate bears an antero-ventral condyle that articulates with the 184 anguloarticular. The anterior portion of the suspensorium is poorly preserved, and it is difficult to 185 outline the limits of the endopterygoid, ectopterygoid and palatine bones. The dorsal and posterior portions of the endopterygoid are preserved, suggesting that the bone forms two laminae, the dorsal one along the parasphenoid, and the ventral one contacting both the quadrate and the metapterygoid.

Both the left and right ventral hyoid arches are visible. One is preserved in life position: its posterior end overlaps the operculum, but its dorsal margin is hidden by the lower jaw, suggesting it corresponds to the right ventral hyoid arch. The left one is displaced and upturned, and lies ventral to its counterpart. The posterior ceratohyal is triangular and articulates with the anterior ceratohyal with an interdigitated suture. The anterior ceratohyal shows a strong ventral concavity at midlength; its dorsal margin is much less concave. The anterior end of the anterior ceratohyal forms a rounded condyle, over which the curved ventral hypohyal articulates. The dorsal hypohyal lies dorsally over the anterior ceratohyal. There are six branchiostegals: the anterior two are shorter and articulate with the anterior ceratohyal at the level of its ventral concavity; the four others articulate more posteriorly (due to the faint distinction between both ceratohyals, it is difficult to determine on which one they articulate); they are very long (the posteriormost being the longest) and curved posteriorly over the ventral margin of the interopercle. The branchiostegals of the left hyoid arch are disarticulated. 


\section{Opercular series}

204 The preopercle is wide and angled at mid-length. The interopercle is an elongate bone rounded at

205 its extremity that forms the ventral margin of the opercular series. It has a smooth ventral margin,

206 closely associated with the posterior branchiostegals. The possible presence of parts of the

207 opercle, in contact with the preopercle, is unclear.

208

209

\section{Dorsal fin and supports}

210

The dorsal fin is only partially preserved, with only the most anterior pterygiophores and dorsalfin rays visible. Its most striking feature is the extremely elongated and enlarged first dorsal-fin ray, which is 10 times as wide as the more posterior fin rays (at their base and greatest width). It does not bifurcate distally, lacks any visible segmentation, and a groove runs throughout its length. A rounded splint protrudes at its anterior base; it is unclear whether it constitutes a separate dorsal-fin element or not. Fifteen other dorsal-fin rays are preserved posteriorly. Their distal end is missing in most cases, but they all seem to be of a similar length, except for the second and third dorsal-fin rays that are noticeably longer. They do not bifurcate distally, and no segmentation is clearly visible.

219 Ten dorsal-fin pterygiophores are clearly preserved. They are strongly inclined anteriorly, which causes the dorsal fin to originate at the tip of the crest, and to run along the entire head of the animal. The first two dorsal-fin pterygiophores are greatly enlarged and in close contact with the crest. Both also show a conspicuous flange at their posterior margin. The first pterygiophore is narrow posteriorly, where it does not contact the supraoccipital, and widens in its distal end. The second one is much wider and slightly narrows at its distal extremity. It is in close contact with 
225 the first pterygiophore throughout its entire length. The third and fourth preserved

226 pterygiophores are in close contact with the second one throughout almost all of their lengths.

227 The more posterior pterygiophores have a mostly straight shaft that curves slightly at its distal

228 extremity. The most posterior ones are less inclined than the anterior ones. The proximal ends of

229 all preserved pterygiophores converge at the same point: the base of the crest - thus they insert

230 anterior to the (not preserved) first neural spine. The elongated and enlarged first dorsal-fin ray

231 inserts on the first pterygiophore. It is unclear if the rays two to eight insert on pterygiophores

232 that are mostly hidden or not preserved, or in supernumerary association with the enlarged

233 second pterygiophore. The rays 9-16 each insert serially on a corresponding pterygiophore.

\section{DISCUSSION}

\section{Taxonomic justification}

237 Oelschläger (1979) proposed that MNHN.F. EIP11 is different enough anatomically from the other lophotids, fossil and extant, to justify its attribution to a new genus. Indeed, it differs from the holotype of $\uparrow$ Protolophotus, found in the same geological levels, by the relative development of the crest. In MNHN.F.EIP11, the crest is projecting anteriorly with an angle of $64.5^{\circ}$, and the ratio between the lengths of the crest's anterior margin and of the head without the crest is of crest is almost vertical (degree of projection: $20^{\circ}$ ), and it is relatively shorter (margin of the crest/head length without the crest: 0.67/1). MNHN.F.EIP11 also bears a much stronger first dorsal-fin ray, and its two anterior dorsal-fin pterygiophores are considerably more developed. Body size is known to affect crest size and degree of projection in extant Lophotus (Craig,

247 Hastings \& Pondella, 2004), which could be misleading when trying to differentiate taxa based 
248 on morphology. However, this bias can probably be ruled out in the case of MNHN.F.EIP11 and

249 MNHN.F.EIP10: both individuals have similar head lengths without the crest (42 and $44 \mathrm{~mm}$,

250 respectively), suggesting that they are at a similar growth stage. It then seems that classifying

251 MNHN.F.EIP11 in a different genus and species, $\uparrow$ Babelichthys olneyi, is justified from a

252 morphological point of view.

253

254 Systematic position

255 Babelichthys as a taeniosome lampridiform

256 The monophyly of Lampridiformes (excluding Stylephorus, sensu Nelson, Grande \& Wilson,

257 2016) is well-supported by molecular phylogenetic analyses (Wiley, Johnson \& Dimmick, 1998;

258 Miya et al., 2007; Betancur-R. et al., 2013; Near et al., 2013) and by numerous morphological

259 features (Olney, Johnson \& Baldwin, 1993; Davesne et al., 2014, 2016; Delbarre, Davesne \&

260 Friedman, 2016). Several of these character states are unambiguously found in $\dagger$ Babelichthys:

261 the premaxilla and dentary are toothless, the frontal and the supraoccipital are both involved in a

262 sagittal crest, the anterior ceratohyal forms a condyle that articulates with the ventral hypohyal,

263 and the first dorsal-fin pterygiophore inserts anterior to the neural spine of the first abdominal

264 vertebra.

265 The phylogenetic studies that explore lampridiform intrarelationships with a sufficient sampling

266 all recover a monophyletic Taeniosomi (Wiley, Johnson \& Dimmick, 1998; Grande, Borden \&

267 Smith, 2013; Martin, 2015). The taeniosome character states found in $\uparrow$ Babelichthys include the

268 absence of supraneurals, and anterior dorsal-fin pterygiophores that are enlarged and inclined

269 over the neurocranium (Olney, Johnson \& Baldwin, 1993). $\uparrow$ Babelichthys then clearly shows a

270 character state combination that confirms its identification as a taeniosome lampridiform. 


\section{Position within Lophotidae}

273 Olney, Johnson \& Baldwin (1993) proposed that the enlarged supraoccipital process, projecting

274 anteriorly over the frontals (forming the "crest" as described herein) and supporting the first dorsal-fin pterygiophore, is a synapomorphy of Lophotidae. Since it is not observed elsewhere in lampridiforms, this character confirms the attribution of $\uparrow$ Babelichthys to Lophotidae. It has to

277 be noted that in the yet unpublished phylogenetic analysis of Martin (2015), the monophyly of Lophotidae is ambiguous, with one parsimonious tree finding Lophotus more closely related to the other taeniosomes than to Eumecichthys, while in the other both genera are sister groups. Given this ambiguity, Lophotidae is kept as a monophyletic group in this discussion.

The distinction between an almost horizontal "crest" projecting anteriorly and a more vertical and relatively shorter "crest" distinguishes $\uparrow$ Babelichthys from $\uparrow$ Protolophotus (see above, Taxonomic justification), but also from the extant Lophotus and the other known lophotid fossil taxa (Table 1). Conversely, in the Eumecichthys specimen that is examined, the crest is strongly projected anteriorly (angle of $72.4^{\circ}$ ) and relatively very long (Table 1). Another element is the apparent absence of vomerine fang-like teeth in $\uparrow$ Babelichthys (it is however possible that they were present, but not preserved in the fossil), like in Eumecichthys, while they are present in Lophotus (Olney, Johnson \& Baldwin, 1993). Since only one specimen is available, it is impossible to perform a thorough comparison of head morphologies at various growth stages and between individuals. Nevertheless, it seems based on available elements that head morphology in $\uparrow$ Babelichthys is closer to the one observed in Eumecichthys than in Lophotus, corroborating Oelschläger's (1979) proposition that it represents a potential fossil sister group to Eumecichthys.

293 It would then be the first known fossil unicorn crestfish. Nevertheless, $\uparrow$ Babelichthys also differs 
294 from Eumecichthys: its crest is less strongly projecting and relatively shorter (Table 1).

295 Moreover, no other lophotid, fossil or extant, has such an extreme enlargement and expansion of 296 the dorsal-fin pterygiophores, in particular the second one.

297

\section{The taeniosome fossil record}

299 Taeniosome lampridiforms are known by several fossil representatives. The oldest

300 unquestionable occurrences are all attributed to Lophotidae: the diminutive $\dagger$ Eolophotes lenis

301 (Fig. 4A), from the Lutetian (Eocene) of Georgia (Daniltshenko, 1962, 1980) and

$302 \uparrow$ Protolophotus elami (Fig. 3), found in the same middle-late Eocene formation as $\dagger$ Babelichthys

303 (see above). An additional, younger fossil lophotid is †Oligolophotes fragosus (Fig. 4B) from the

304 early Oligocene Pshekha Formation of Adygea, northern Caucasus, Russia (Bannikov, 1999).

305 The taeniosome fossil record also includes the trachipterid $\dagger$ Trachipterus mauritanicus from the

306 Messinian (late Miocene) of Algeria (Carnevale, 2004), and a fragmentary possible oarfish

307 (Regalecus) from the Pliocene of Italy (Bronzi, 2001; Roberts, 2012). There is no known fossil

308 Radiicephalidae. Finally, the small and distinctive $\dagger$ Bajaichthys elegans, from the Ypresian

309 (early Eocene) of Bolca, Italy, has been classified as a taeniosome or close relative due to its

310 mobile jaws, elongate body and reduced caudal fin (Sorbini \& Bottura, 1988; Bannikov, 2014).

311 However, it can be confidently classified in Zeiformes, another teleost clade (Davesne,

312 Carnevale \& Friedman, 2017). In total, five entirely fossil species of taeniosomes are currently

313 known (four Lophotidae, one Trachipteridae), a diversity expanded by the present description of

$314 \dagger$ Babelichthys.

315

316 CONCLUSION 
317 In the present paper, $\dagger$ Babelichthys olneyi, a new genus and species of Lophotidae from the

318 Eocene of Iran is described. Few fossil representatives of Taeniosomi, an elusive group of deep-

319 sea teleosts, are known and only one of them has been previously described in detail (Bannikov,

320 1999). $\uparrow$ Babelichthys is potentially the only known fossil close relative of the unicorn crestfish

321 Eumecichthys. This discovery is also significant because it expands the diversity of the middle-

322 late Eocene Ilam fauna. Modern lophotids are found in mesopelagic environments (Olney, 2002),

323 so the presence of at least two representatives of the family in the fauna that is mostly composed

324 by relatives of modern deep-sea teleosts (Arambourg, 1967; Afsari et al., 2014; Přikryl,

325 Brzobohatý \& Gregorová, 2016) reinforces the assumption that it represents a valuable glimpse

326 of the poorly known early Cenozoic deep-water ecosystems.

327

328

Institutional Abbreviations

329

330

331

332

333

334

335

336

337

338

339

MNHN, Muséum national d'Histoire naturelle, Paris, France; NHMUK, Natural History

Museum, London, United Kingdom; PIN, Borisyak Paleontological Institute of the Russian

Academy of Sciences, Moscow, Russia; USNM, National Museum of Natural History,

Smithsonian Institution, Washington D.C., United States.

\section{ACKNOWLEDGEMENTS}

The author thanks Gaël Clément (MNHN) for allowing access to the specimen of study, Alexandre Bannikov (PIN) for his useful information on the lampridiform fossil record and for suggesting the redescription of this specimen, as well as Giorgio Carnevale (Università degli Studi di Torino) for insightful anatomical discussion. Sandra Raredon (USNM) kindly sent radiographs of extant lophotids for comparison, while Lilian Cazes, Philippe Loubry (MNHN) 
340

341

342

343

344

345

346

347

348

349

350

351

352

353

354

355

356

357

358

359

360

361

362

and A. V. Mazin (PIN) provided high-quality photographs of the fossil specimens. Finally, the editor Jérémy Anquetin and referees Alexandre Bannikov and Dave Johnson are thanked for their invaluable reviews and comments.

\section{REFERENCES}

Afsari S., Yazdi M., Bahrami A., Carnevale G. 2014. A new deep-sea hatchetfish (Teleostei: Stomiiformes: Sternoptychidae) from the Eocene of Ilam, Zagros Basin, Iran. Bollettino della Società Paleontologica Italiana 53:27-37. DOI: 10.4435/BSPI.2014.03.

Arambourg C. 1943. Note préliminaire sur quelques Poissons fossiles nouveaux. Bulletin de la Société Géologique de France 5:281-288.

Arambourg C. 1967. Résultats Scientifiques de la Mission C. Arambourg en Syrie et en Iran (1938-1939). II. Les Poissons Oligocènes de l'Iran. Notes et Mémoires sur le Moyen-Orient $8: 1-210$

Bannikov AF. 1999. A review of fossil Lampridiformes (Teleostei) finds with a description of a new Lophotidae genus and species from the Oligocene of the Northern Caucasus. Paleontological Journal 33:68-76.

Bannikov AF. 2014. A new genus of the family Palaeocentrotidae (Teleostei, Lampridiformes) from the Oligocene of the Northern Caucasus and comments on other fossil Veliferoidei. Paleontological Journal 48:624-632. DOI: 10.1134/S0031030114060021.

Betancur-R. R., Broughton RE., Wiley EO., Carpenter K., López JA., Li C., Holcroft NI., Arcila D., Sanciangco M., Cureton JC., Zhang F., Buser T., Campbell MA., Ballesteros JA., RoaVarón A., Willis S., Borden WC., Rowley T., Reneau PC., Hough DJ., Lu G., Grande T., Arratia G., Ortí G. 2013. The tree of life and a new classification of bony fishes. PLoS 
363

364

365

366

367

Currents Tree of Life 2013 Apr 1. DOI:

\subsection{1/currents.tol.53ba26640df0ccaee75bb165c8c26288}

Bonaparte CL. 1845. Specchio generale del sistema ittiologico. Atti della sesta Riunione degli Scienziati Italiani 6:386-390.

Bronzi P. 2001. Regalecus cf. glesne, prima segnalazione dal Pliocene marchigiano. Fossili \& Fossili, Centro studi e ricerche geopaleontologici di Sigillo 2:39-42.

Carnevale G. 2004. The first fossil ribbonfish (Teleostei, Lampridiformes, Trachipteridae). Geological Magazine 141:573-582. DOI: 10.1017/S0016756804009598.

Craig MT., Hastings PA., Pondella DJ. 2004. Notes on the systematics of the crestfish genus Lophotus (Lampridiformes: Lophotidae), with a new record from California. Bulletin Southern California Academy of Sciences 103:57-65.

Daniltshenko PG. 1962. Fishes from the Dabhakan Formation of Georgia. Paleontologicheskii Zhurnal 1:111-126.

Daniltshenko PG. 1980. Order Lampridiformes. Pp. 91-96 in: Iskopayemyye kostistyye ryby SSSR [Fossil bony fishes of the USSR]. Trudy Paleontologicheskogo Instituta, Akademiya Nauk CCCP 178.

Davesne D., Carnevale G., Friedman M. 2017. Bajaichthys elegans from the Eocene of Bolca (Italy) and the overlooked morphological diversity of Zeiformes (Teleostei, Acanthomorpha). Palaeontology 60:255-268. DOI: 10.1111/pala.12280.

Davesne D., Friedman M., Barriel V., Lecointre G., Janvier P., Gallut C., Otero O. 2014. Early fossils illuminate character evolution and interrelationships of Lampridiformes (Teleostei, Acanthomorpha). Zoological Journal of the Linnean Society 172:475-498. DOI: 10.1111/zoj.12166. 
386 Davesne D., Gallut C., Barriel V., Janvier P., Lecointre G., Otero O. 2016. The phylogenetic

387 intrarelationships of spiny-rayed fishes (Acanthomorpha, Teleostei, Actinopterygii): fossil

388 taxa increase the congruence of morphology with molecular data. Frontiers in Ecology and

389 Evolution 4:129. DOI: 10.3389/fevo.2016.00129.

390 Delbarre DJ., Davesne D., Friedman M. 2016. Anatomy and relationships of $\uparrow$ Aipichthys

391 pretiosus and †"Aipichthys" nuchalis (Acanthomorpha: Lampridomorpha), with a review of

392 Late Cretaceous relatives of oarfishes and their allies. Journal of Systematic Palaeontology

$393 \quad 14: 545-567$. DOI: 10.1080/14772019.2015.1078538.

394 Gill T. 1885. Sub-order XII - Taeniosomi. In: Kingsley JS ed. The Standard Natural History.

395 Boston: S. E. Cassino and Co., 265-267.

396 Goodrich ES. 1909. Part IX. Vertebrata Craniata (First Fascicle: Cyclostomes and Fishes). In:

397 A Treatise on Zoology. London: Adam and Charles Black.

398 Grande T., Borden WC., Smith WL. 2013. Limits and relationships of Paracanthopterygii: A

399 molecular framework for evaluating past morphological hypotheses. In: Arratia G, Schultze

400 H-P, Wilson MVH eds. Mesozoic Fishes 5 - Global Diversity and Evolution. Munich:

$401 \quad$ Verlag Dr. Friedriech Pfeil, 385-418.

402 Harrisson CMH., Palmer G. 1968. On the neotype of Radiicephalus elongatus Osório with

403 remarks on its biology. Bulletin of the British Museum (Natural History) Zoology 16:187-

$404 \quad 211$.

405 Honma Y., Ushiki T., Takeda M. 1999. Histology of the ink tube and its associated organs in a

406 unicornfish, Eumecichthys fiskii (Lampridiformes). Ichthyological Research 46:19-25.

407 International Commission on Zoological Nomenclature. 1999. International Code of Zoological

$408 \quad$ Nomenclature. 4th Edition. 
409 Martin JM. 2015. Phylogeny, ontogeny and distribution of the ribbonfishes (Lampridiformes:

410 Trachipteridae). PhD thesis, College of William \& Mary, Williamsburg, Virginia, USA.

411 Miya M., Holcroft NI., Satoh TP., Yamaguchi M., Nishida M., Wiley EO. 2007. Mitochondrial

412 genome and a nuclear gene indicate a novel phylogenetic position of deep-sea tube-eye fish (Stylephoridae). Ichthyological Research 54:323-332. DOI: 10.1007/s10228-007-0408-0.

414

415

416

417

418

419

420

421

422

423

424

425

426

427

428

429

430

431

Müller J. 1845. Über den Bau und die Grenzen der Ganoiden, und über das natürliche System der Fische. Abhandlungen der Königlichen Akademie der Wissenschaften zu Berlin 1844:117-216.

Near TJ., Dornburg A., Eytan RI., Keck BP., Smith WL., Kuhn KL., Moore JA., Price SA., Burbrink FT., Friedman M., Wainwright PC. 2013. Phylogeny and tempo of diversification in the superradiation of spiny-rayed fishes. Proceedings of the National Academy of Sciences 110:12738-12743. DOI: 10.5061/dryad.d3mb4.

Nelson JS., Grande TC., Wilson MVH. 2016. Fishes of the World, Fifth Edition. Hoboken, New Jersey: John Wiley \& Sons.

Oelschläger HA. 1979. Zur funktionellen Osteologie der Lophotidae (Pisces: Teleostei). Zoologische Jahrbücher 102:336-360.

Oelschläger HA. 1983. Vergleichende und funktionelle Anatomie der Allotriognathi (= Lampridiformes), ein Beitrag zur Evolutionsmorphologie der Knochenfische. Abhandlungen der Senckenbergischen Naturforschenden Gesellschaft 541:1-127.

Olney JE. 1984. Lampriformes: development and relationships. In: Moser HG, Richards WJ, Cohen DM, Fahay MP, Kendall AW, Richardson SL eds. Ontogeny and Systematics of Fishes, Special Publication Number 1, American Society of Ichthyologists and Herpetologists. Lawrence, Kansas: Allen Press, 368-379. 
432 Olney JE. 2002. Lophotidae, Radiicephalidae, Trachipteridae, Regalecidae. In: Carpenter KE ed. 433 The Living Marine Resources of the Western Central Atlantic. Volume 2: Bony Fishes part

Olney JE., Johnson GD., Baldwin CC. 1993. Phylogeny of lampridiform fishes. Bulletin of

438 Marine Science 52:137-169.

Priem F. 1908. Poissons fossiles de Perse. Annales d'Histoire Naturelle, Paléontologie 1:1-25.

Přikryl T., Brzobohatý R., Gregorová R. 2016. Diversity and distribution of fossil codlets (Teleostei, Gadiformes, Bregmacerotidae): review and commentary. Palaeobiodiversity and Palaeoenvironments 96:13-39. DOI: 10.1007/s12549-015-0222-z.

Regan CT. 1907. On the anatomy, classification, and systematic position of the teleostean fishes of the suborder Allotriognathi. Proceedings of the Zoological Society of London 1907:634643.

Roberts TR. 2012. Systematics, Biology and Distribution of the Species of the Oceanic Oarfish Genus Regalecus (Teleostei, Lampridiformes, Regalecidae). Paris: Publications Scientifiques du Muséum.

Rosen DE. 1973. Interrelationships of higher euteleostean fishes. In: Greenwood PH, Miles RS, Patterson C eds. Interrelationships of Fishes. London: Academic Press, 397-513.

Sorbini L., Bottura C. 1988. Bajaichthys elegans, an Eocene lampridiform from Bolca (Italy). Bollettino del Museo Civico di Storia Naturale di Verona 14:369-380.

Walters V. 1957. Protolophotus, a new genus of allotriognath fish from the Oligocene of Iran. Copeia 1:60-61.

Walters V., Fitch JE. 1960. The families and genera of the Lampridiform (Allotriognath) 
suborder Trachipteroidei. California Fish and Games 46:441-451.

456 Wiley EO., Johnson GD., Dimmick WW. 1998. The phylogenetic relationships of lampridiform

457

458

459

460

461

462

463

464

465

466

467

468

469

470

471

472

473

474

475

476 $477=10 \mathrm{~mm}$. fishes (Teleostei: Acanthomorpha), based on a total-evidence analysis of morphological and molecular data. Molecular Phylogenetics and Evolution 10:417-425. DOI:

10.1006/mpev.1998.0532.

\section{Figure captions}

FIGURE 1. $†$ Babelichthys olneyi, gen. et sp. nov., holotype. (A) MNHN.F.EIP11d. (B) counterpart MNHN.F.EIP11g. Scale bars $=20 \mathrm{~mm}$.

FIGURE 2. $†$ Babelichthys olneyi, gen. et sp. nov. holotype MNHN.F.EIP11d. (A) Photograph

(detail of the head) and (B) interpretative drawing. Legend: achy, anterior ceratohyal; bra, branchiostegal; bsp, basisphenoid; den, dentary; dfr, dorsal-fin ray; dhhy, dorsal hypohyal; dpt, dorsal-fin pterygiophore; enpt, endopterygoid; fr, frontal; hyo, hyomandibula; iop, interopercle; lac, lachrymal; let, lateral ethmoid; mpt, metapterygoid; mx, maxilla; osp, orbitosphenoid; pal, palatine; pchy, posterior ceratohyal; pmx, premaxilla; pop, preopercle; psp, parasphenoid; qu, quadrate; soc, supraoccipital; soc-sp, spine of the supraoccipital; spl, splint of the first dorsal-fin ray; vhhy, ventral hypohyal; vo, vomer. Scale bar $=10 \mathrm{~mm}$.

FIGURE 3. $\uparrow$ Protolophotus elami, holotype MNHN.F.EIP10d. Scale bar $=20 \mathrm{~mm}$.

FIGURE 4. Other fossil taxa attributed to family Lophotidae. (A) †Eolophotes lenis, holotype PIN 1413/86; scale bar $=5$ mm. (B) †Oligolophotes fragosus, holotype PIN 3363/121; scale bars 
Figure 1

†Babelichthys olneyi, gen. et sp. nov., holotype.

(A) MNHN.F.EIP11d. (B) counterpart MNHN.F.EIP11g. Scale bars $=20 \mathrm{~mm}$.
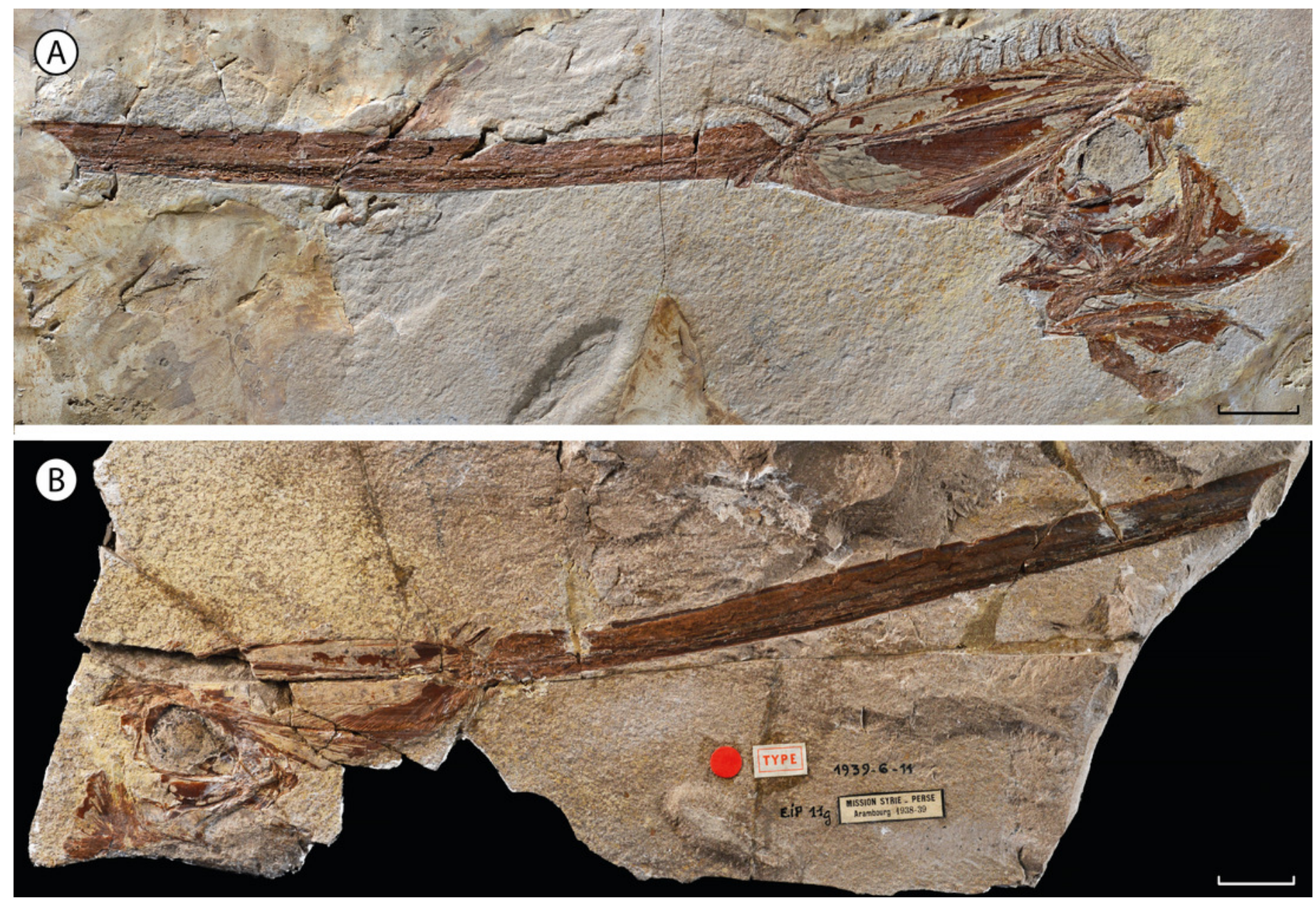


\section{Figure 2 (on next page)}

†Babelichthys olneyi, gen. et sp. nov. holotype MNHN.F.EIP11d.

Photograph (detail of the head) and interpretative drawing. Legend: achy, anterior ceratohyal; bra, branchiostegal; bsp, basisphenoid; den, dentary; dfr, dorsal-fin ray; dhhy, dorsal hypohyal; dpt, dorsal-fin pterygiophore; enpt, endopterygoid; fr, frontal; hyo, hyomandibula; iop, interopercle; lac, lachrymal; let, lateral ethmoid; mpt, metapterygoid; mx, maxilla; osp, orbitosphenoid; pal, palatine; pchy, posterior ceratohyal; pmx, premaxilla; pop, preopercle; psp, parasphenoid; qu, quadrate; soc, supraoccipital; soc-sp, spine of the supraoccipital; spl, splint of the first dorsal-fin ray; vhhy, ventral hypohyal; vo, vomer. Scale bar $=10 \mathrm{~mm}$. 


\section{Figure 3}

†Protolophotus elami, holotype MNHN.F.EIP10d.

Scale bar $=20 \mathrm{~mm}$.

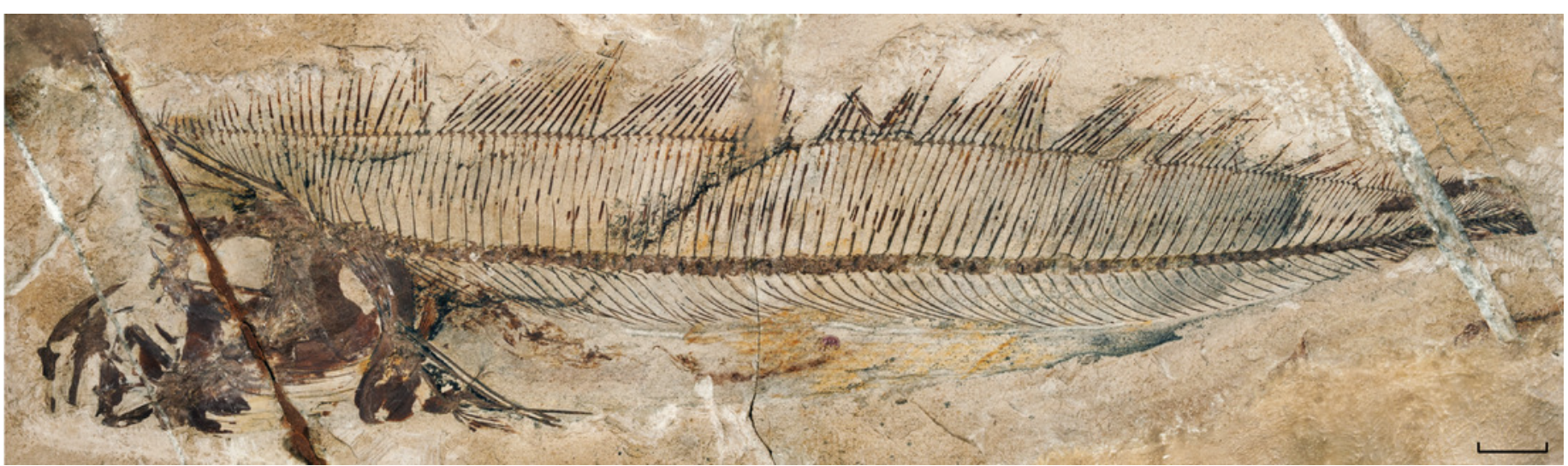




\section{Figure 4}

Other fossil taxa attributed to family Lophotidae.

(A) †Eolophotes lenis, holotype PIN 1413/86; scale bar $=5 \mathrm{~mm}$. (B) †Oligolophotes fragosus, holotype PIN 3363/121; scale bars $=10 \mathrm{~mm}$.
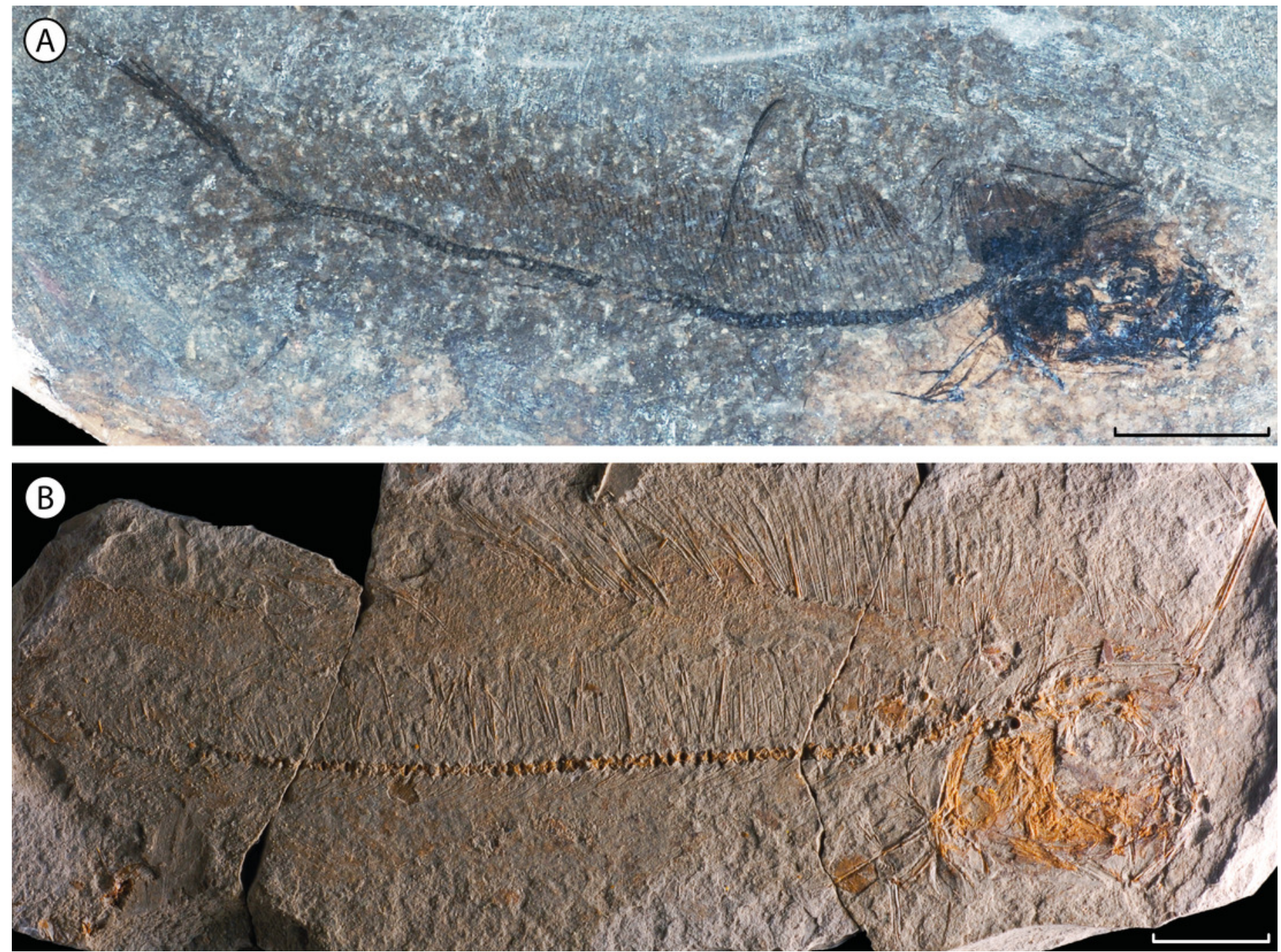


\section{Table $\mathbf{1}$ (on next page)}

Comparison between crest measurements in selected specimens of known lophotid genera.

${ }^{1}$ Angle $\left({ }^{\circ}\right)$ between the straight line from the tip of the crest to the proximal end of its anterior margin, and the line drawn perpendicular to the main axis of the parasphenoid.

${ }^{2}$ Distance $(\mathrm{mm})$ between the tip of the crest to the proximal end of its anterior margin.

${ }^{3}$ Distance $(\mathrm{mm})$ between the anterior margin of the ethmoid and the posterior margin of the neurocranium 


\begin{tabular}{|l|l|l|l|l|l|}
\hline Species & Specimen studied & $\begin{array}{l}\text { Projection of } \\
\text { the }^{\text {crest }}{ }^{1}\end{array}$ & $\begin{array}{l}\text { Crest } \\
\text { length }\end{array}$ & $\begin{array}{l}\text { Head } \\
\text { length }\end{array}$ & $\begin{array}{l}\text { Crest length / } \\
\text { head length }\end{array}$ \\
\hline $\begin{array}{l}\dagger \text { Babelichthys } \\
\text { olneyi, sp. nov. }\end{array}$ & MNHN.F.EIP11 & $64.5^{\circ}$ & $51.5 \mathrm{~mm}$ & $44 \mathrm{~mm}$ & $1.17 / 1$ \\
\hline $\begin{array}{l}\dagger \text { Protolophotus } \\
\text { elami }\end{array}$ & MNHN.F.EIP10 & $20^{\circ}$ & $28 \mathrm{~mm}$ & $42 \mathrm{~mm}$ & $0.67 / 1$ \\
\hline$\dagger$ Eolophotes lenis & PIN 1413/86 & $-17^{\circ}$ & $1.1 \mathrm{~mm}$ & $2.1 \mathrm{~mm}$ & $0.52 / 1$ \\
\hline $\begin{array}{l}\dagger \text { Oligolophotes } \\
\text { fragosus }\end{array}$ & PIN 3363/121 & $6.7^{\circ}$ & $6.8 \mathrm{~mm}$ & $12.7 \mathrm{~mm}$ & $0.54 / 1$ \\
\hline $\begin{array}{l}\text { Lophotus lacepede } \\
\text { NHMUK }\end{array}$ & $\begin{array}{l}\text { NHM } \\
1863.8 .27 .1\end{array}$ & $25.7^{\circ}$ & $99.8 \mathrm{~mm}$ & $\begin{array}{l}108.6 \\
\mathrm{~mm}\end{array}$ & $0.92 / 1$ \\
\hline Eumecichthys fiski & USMN 164170 & $72.4^{\circ}$ & $26.8 \mathrm{~mm}$ & $17.2 \mathrm{~mm}$ & $1.55 / 1$ \\
\hline
\end{tabular}

1

2 TABLE 1. Comparison between crest measurements in selected specimens of known lophotid 3 genera.

4

$5 \quad{ }^{1}$ Angle $\left({ }^{\circ}\right)$ between the straight line from the tip of the crest to the proximal end of its anterior 6 margin and the line drawn perpendicular to the main axis of the parasphenoid.

$7 \quad 2$ Distance $(\mathrm{mm})$ between the tip of the crest to the proximal end of its anterior margin.

$8{ }^{3}$ Distance $(\mathrm{mm})$ between the anterior margin of the ethmoid and the posterior margin of the 9 neurocranium 